patologickým jevům). Acquaviva nicméně požadavek na inkluzivní péči o LGBTQ formuluje především jako požadavek na péči, jež respektuje individuální životní historii jednotlivce a specifický kontext jeho života. Troufám si říct, že to je péče, o kterou by stál/a každý/á z nás.

\title{
Věk v akci
}

\section{Iva Šmídová}

Hearn, J., Parkin, W. 2021. Age at Work: Ambiguous Boundaries of Organizations, Organizing and Ageing. Los Angeles, London, New Delhi, Singapore, Washington, DC, Melbourne: SAGE.

Jeff Hearn a Wendy Parkin nabízejí pestrý pohled na to, co si spojuje sociologie s věkem a stárnutím. "Věk v akci” (nejen v práci), jak by se dal název knihy Age at Work volně přeložit, netematizuje jen sféru pracovních organizací, jak navozuje její podtitul. Přibližuje vztahy, procesy a dělání organizací, do kterých se zejména jako zralí a stárnoucí lidé, ale poté i posmrtně, dostáváme.

Vlastně už jsme málem odvykli používat výraz "věk", potlačil jej termín spojený se stárnutím populací i individuí. A kniha je v tomto smyslu od autorů dobrou připomínkou řady zjednodušení a stereotypů, jež se na dělání věku a organizací nabalují. Kombinuje prìtom jak reflexe konceptuální, tak biografické. Pracuje s opomíjeným, připomínaným i vzpomínaným nebo zapomínaným. A je to skvělé i napínavé čtení.

První část knihy (po úvodu), sepsaná ve spoluautorstvís Richardem Howsonem, nabízí teoretičtější, konceptuální pohledy na to, jak pracovat s věkem, který hraje roli ve všech etapách života, nejen ve stáří. Dále se autoři ve spolupráci s Charlottou Niemstö zaměřili na konkrétní režimy fungování a dělání organizací s ohledem na věk a stárnutí. Druhá část knihy představuje, jak věk organizuje a spoluvytváří kontext, podoby i cíle, strukturu, procesy, ale i každodennost organizací. Nejobsáhlejší, závěrečnou část knihy dvojice hlavních autorů věnuje hraničním záležitostem věku a organizací (či organizování). Podobně jako v úvodní kapitole publikace se vracejí také k autobiografickému přístupu a s odkazem na vlastní věk zařazují kapitoly o etapě „po životě”, překročení konečné hranice (smrti) a organizování věcí posmrtných, bezpřítomných.

Jak na začátku, tak i na konci knihy autoři reflektují, problematizují a otevírají další pole a oblasti nejasností, rozmazaných hranic a přechodů, nebo naopak nabízejí rozostření těch mantinelů, které sami dosud považujeme za nepřekročitelné a konečné. 


\section{NV/ RECENZE / BOOK REVIEWS}

Připomínají zapomenuté a neviditelné (věk v jednotlivých etapách života, organizaci věku institučními pravidly i sociálním ráádem) a nabízejí uznání a (roz)poznání těchto neviditelností ze zkušenosti, jak sami stárli a stárnou. Sami přitom promýšlejí a píšou knihu o věku v práci či v organizacích koncepčně, strukturovaně. Vymezují věk a stárnutí (nebo také zralost) ve vztahu k dalším strukturujícím kategoriím sociální analýzy, jako jsou gender, třída. Činí tak jak v rovině individuálních biografií, generačních vztahů, tak i kulturních konstrukcí toho, jak, kde a kdo definuje(me) "stáří", nebo jaké významy přikládáme různým etapám zralosti (věku, stáří). Autoři rovněž dekonstruují koncept organizací a přistupují k němu kriticky, nepovažují jej za danost či fixní věc, ale za výslednici konstelací, vztahů a praxe, v níž dominuje určitý segment dospělých, a to v oblasti ekonomiky, státu či občanské společnosti (s. 20). Sleduji jak diskursivní, tak materiální perspektivy změn organizačního světa, struktur a procesů.

Věk je jednou ze základních os sociální stratifikace a vztahů a projevuje se rozdílně v odlišných prostředích, společnostech, kulturách, historických obdobích. Funguje obdobně, ale ne stejně jako gender - věk je všudypř́tomný a samozřejmý bez reflexe nerovností na něj vázaných. Věk není jen vlastností jedinců, jejich životy organizační pravidla konsolidují a strukturují. Organizace a věk se propojují do dělání věku (age work, s. 22).

Kniha je obsahově i analyticky zaměřena na marginalizaci lidí (a jejich organizací) ve zralém a starším věku, k jejich periferním pozicím a ageismu spojenému s tím, kdy se z osob v pracovních organizacích stávají konzumenti jejich služeb. Tato praxe dopadá samozřejmě jak na politiku věku a potřeby její zásadní změny pro každodenní životy a nerovnosti, tak na způsoby, jakým věk a organizace zkoumáme a studujeme - zvlášt' i společně - i tomu se kapitoly knihy věnují.

Celý text je provázaný, vzájemně odkazuje na jednotlivé pasáže a témata představená v knize. Zưstává přitom čtivý a snadno srozumitelný, jeho "hyperlinková" podoba tak zdưrazňuje komplexitu intersekcionálního tématu, ale i velmi zdařilou autorskou a editorskou práci. Osobně mi připadalo inspirující, až napínavé pročítat velmi osobní, zkušenostní přístup autorů propojený jasnou červenou nití ve "velkém vyprávění" plném různých zákoutí, meandrů i temných míst konceptualizace "věku v práci”. Kniha zůstává přístupná široké škále odborně zaměřených čtenářek a čtenářu nejen z oblasti studií nerovností, organizační kultury, stratifikace, intersekcionality, stárnutí nebo genderu, ale i těm, pro něž se studium životního cyklu kritickou sociologickou perspektivou teprve začíná otevírat. 